\title{
REFURBISHING EARTHQUAKE RISK BUILDINGS IN U.S.A.
}

\author{
D.B. Leadbeater*
}

SYNOPSIS:

The paper reviews current ordinances and standards in use and under discussion on the western seaboard of the United States with particular refererce to the cities of Seattle, Sacramento, Santa Rosa, Long Beach, Los Angeles and San Francisco. Details of various upgrading methods and testing procedures are included. In New zealand, both the objective and standards required to achieve that objective appear far more clear. Some personal thoughts are given on a more systematic approach to the upgrading of high earthquake risk buildings in this country.

\section{PREAMBLE:}

Current ordinances and standards relating to the upgrading of high earthquake risk buildings, both operative and under discussion, on the seismically active western seaboard of the United States can provide much useful background material for developing suitable guidelines relevant to this country. The procedures are supported by considerable laboratory and on-site full scale testing. Upgrading methods are relatively straight forward and appear to have direct application here.

In New Zealand, guidelines for the reduction in hazards associated with high earthquake risk buildings are far from clear. Unless urgency is given to developing practical standards of proven necessity, closely related to economic and social reality the present unsatisfactory lack of statutory clarity, variety of standards and interpretation will continue, with all parties, namely; developers, property owners, architects, engineers, contractors and local authority officers becoming increasingly frustrated and divided in what should be a joint approach to improve public safety.

\section{CURRENT UNITED STATES PRACTICE:}

\subsection{General -}

Only three authorities, namely, Long Beach, Santa Rosa, and Oroville are known to have enacted seismic rehabilitation ordinances. Other cities have carried out considerable work in this field, particularly Los Angeles where some 8,000 old masonry buildings are considered hazardous, the upgrading of which could save more than 7,000 lives and prevent 26,000 casualties in the event of a major shock. In San Francisco, preliminary surveys indicate 11,000 unreinforced masonry buildings with between 3,000 and 40,000 deaths resulting from an earthquake equal in intensity to that of 1906 .

The logistics of enacting upgrading ordinances are substantial and considerable emphasis is being placed on economic and

* City Design Engineer, Auckland City Council

BULLETIN OF THE NEW ZEALAND NATIONAL SOCIETY FOR EARTHOUAKE ENGINEERING, VOL. 14, NO. 2, JUNE 1981 social criteria as well as engineering factors. Upgrading to meet higher standards of fire and egress has been more readily accepted and achieved.

Certain parameters are common to a number of cities :

(a) Upgrading of high earthquake risk buildings is necessary to safeguard life and minimise injury.

(b) A balance between economic and practical reality, and optimum engineering standards has been reached, with upgrading standards somewhat less than standards required for new construction.

(c) Many older buildings can be upgraded to higher standards and refurbished generally, at a cost which is economically attractive compared to the cost of new construction.

(d) The preservation of older buildings is often desirable, but economic considerations must determine the viability of each project for the majority of property owners.

(e) Refurbishing has brought renewed life and vitality to previously depressed areas.

(f) The ordinances to be enforceable must be economically and practically realistic, particularly in relation to the time scale over which the total problem is to be rectified.

(g) Alternative and attractive funding must be available to property owners required to upgrade existing buildings.

(h) Upgrading is an art as much as a science and professional judgement in the use of ordinance standards is essential. Detailed structural analysis, particularly in relation to dynamic forces is not considered worthwhile in the majority of cases.

\subsection{Seattle -}

The City of Seattle and its environs is included in seismic zone 3 of the Uniform Building Code. The City requires in relation to old masonry buildings and all other buildings constructed prior 


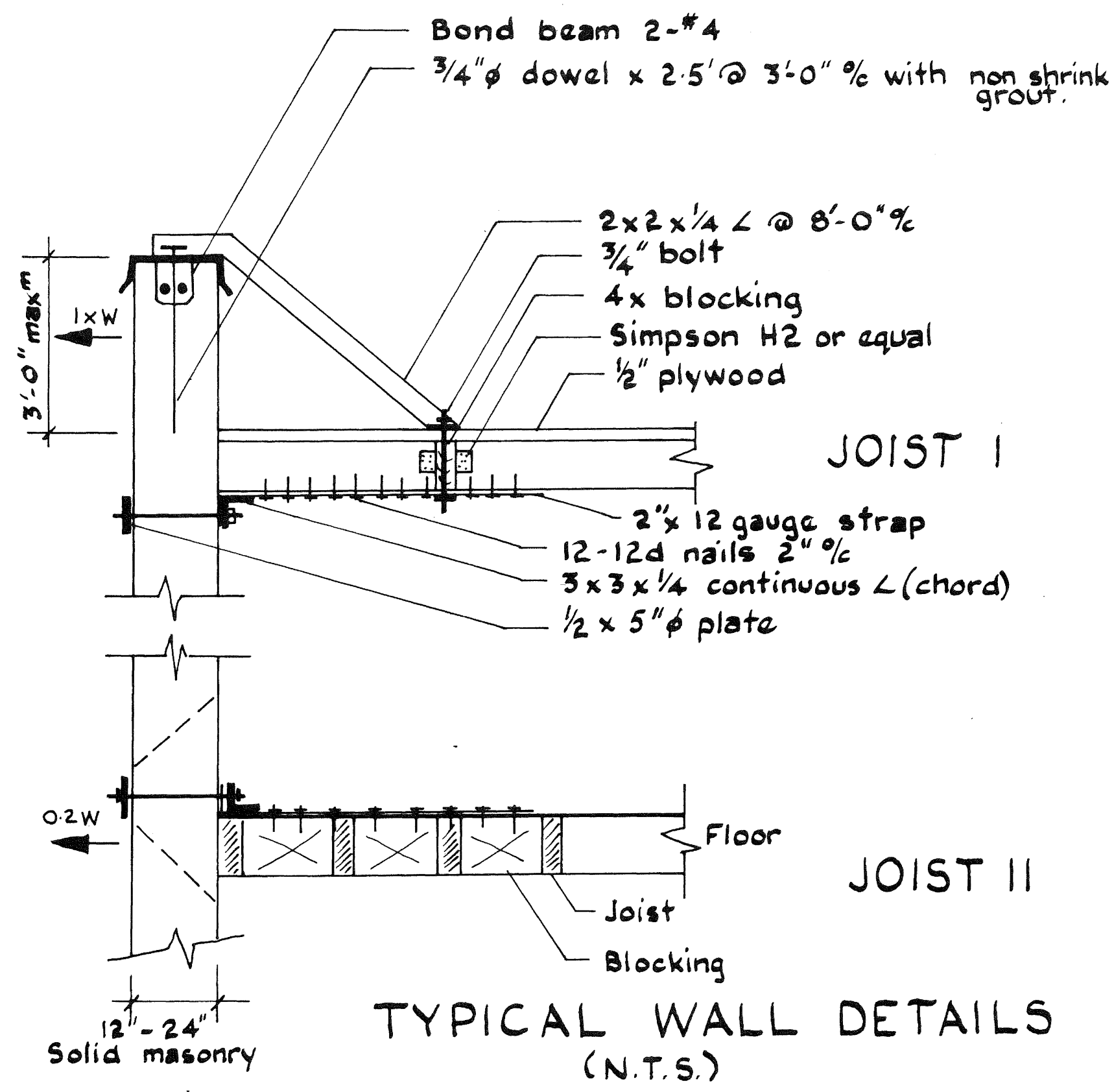

NOTE ON DRAWING

"This structure does not conform to present earthquake code requirements for new buildings. It has been analysed and reinforced in accordance with section 104(e) of the Seattle Building Code and information Bulletin 02, dated 10-20-76 and within current practice for renovation of existing buildings."

Source - Seattle Building Code.

Figure 1 
to 1967, and where substantial alterations or repairs are proposed, that the various building elements when interconnected are able to withstand lateral seismic forces at least equal to the seismic disturbance in Seattle of April 13, 1949 (Richter Scale 7-7.1). include:

Substantial alterations or repairs

(a) Extensive structural repair.

(b) Non-structural repairs totalling over $50 \%$ of the assessed value of the existing building.

(c) Remodelling to substantially extend the life of the building.

(d) A change in use or occupancy that is more hazardous based on life and fire risk, than the existing use.

(e) Alterations or repairs involving a reduction of lateral resistive forces.

The ordinance basically requires the interconnection of walls to roof and floors and the strengthening of parapets and appendages. Typical details, given in Figure 1 , are taken directly from the Seattle Building Code ${ }^{2}$.

The maximum allowable old masonry stresses without substantiating tests are:

$\begin{array}{lrl}\text { Compression } & 100 \mathrm{psi} & (690 \mathrm{kPa}) \\ \text { Combined Tension } & 0 \mathrm{psi} & (0 \mathrm{kPa}) \\ \text { Shear } & 3 \mathrm{psi} & (21 \mathrm{kPa})\end{array}$

Testing has shown that allowable shear stresses up to $40 \mathrm{p.s.i.}(276 \mathrm{kPa})$ are acceptable.

\subsection{Sacramento -}

Code $^{\text {Section }}$ states:

"Historic Buildings.

Repairs, alterations and additions necessary for the preservation, restoration, rehabilitation or continued use of a building or structure may be made without conformance to all the requirements of this code when authorised by the building official provided:

1. The building or structure has been designated by official action of the legally constituted authority of this jurisdiction as having special

historical or architectural significance.

2. Any unsafe conditions as described in this code are corrected.

3. The restored building or structure will be no more hazardous based on life safety, fire safety and sanitation than the existing building."

The lack of clear guidelines and resulting lack of use by local authorities has resulted in the introduction of a state
Historical Building Code in California. The preface notes the need for such a new building code to meet the intent of protecting public health and safety while retaining enough flexibility to allow restoration of a historic feature while still retaining its historic integrity. The regulations are permissive and if adopted by the local authority, allow the use of the Historic Building Code Advisory Board by local authorities requiring advice. Again, the acceptance of such advice is not mandatory. The Code covers a wide area of interest including fire, egress, structural, materials, plumbing, electrical and mechanical requirements.

While the majority of engineers spoken to expressed reservations about the Code, its existance emphasizes the need for reasoned and flexible judgement in setting and approving restoration standards for old buildings.

\subsection{Santa Rosa -}

In 1971 the City of Santa Rosa ${ }^{5}$ resolved that all buildings constructed before December 31, 1957 (except public school buildings and one and two family wood frame dwellings) and all buildings using unreinforced masonry walls be checked for compliance with the Uniform Building Code, 1955 edition. Non compliance requires the upgrading to U.B.C. 1979 levels, however considerable overstress (up to $100 \%$ ) is allowed to meet specific code requirements.

Priority has been given to buildings housing essential services and of high occupancy and to date some 140 buildings have been upgraded. An estimated 500 buildings will require corrective action.

\subsection{Long Beach -}

Bylaws requiring the upgrading of unreinforced masonry buildings for public assembly were first introduced in $1959^{6}$. The most recent bylaw 7 adopted in 1977 requires the upgrading of all masonry buildings constructed prior to 1934 if they do not meet U.B.C. 1970, requirements.

Five critical elements within the building are considered:
(a) Stability of vertical walls
(b) Wall anchorage (perpendicular to diaphragm)
(c) Horizontal diaphragm capacity
(d) Shear connections parallel to shear or moment resisting element
(e) Shear or moment resisting element
The most critical ratio i.e.

$\begin{array}{ll}\text { actual load } & \text { carrying capacity from the } \\ \text { required load } & \text { carrying capacity }\end{array}$

above critical elements, when associated 
with an occupancy classification, weighted to take account of footpath useage, provides a hazard index.

of the total number of buildings requiring upgrading and as ordered by the hazard index, present requirements are that:

$10 \%$ require immediate upgrading or demolition

$30 \%$ require no action prior to 1984 .

$60 \%$ require no action prior to 1991.

A building with a particular hazard e.g. parapet, gable, is placed in the top $10 \%$, however correction of the particular hazard allows reclassification into the appropriate group as determined by the hazard index.

For the purpose of determining actual load carrying capacity the following allowable stresses can be assumed.

Shear and tension

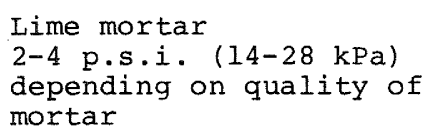

Lime mortar

2-4 p.s.i. $(14-28 \mathrm{kPa})$ depending on quality of mortar

Cement Mortar

$7 \frac{1}{2}$ p.s.i. $(52 \mathrm{kPa})$

Timber diaphragms straight sheathing $501 \mathrm{~b}$ per ft. $(730 \mathrm{~N}$ per $\mathrm{m})$

Diagonal sheathing $300 \mathrm{lb}$ per $\mathrm{ft}$. $(4,380 \mathrm{~N}$ per $\mathrm{m})$ Plywood - as per U.B.C.
code

Approximately 800 buildings to be inspected and graded and this should be completed by December 1980 .

The City is co-orinating a test programme on diaphragm effectiveness using Federal funding.

2.6 Los Angeles -

The expressed purpose of the draft ordinance is to reduce the risk of death or injury arising from seismic forces on unreinforced masonry, bearing wall buildings constructed prior to 1934 . With the exclusion of buildings containing less than five dwelling units, four classifications have been introduced:

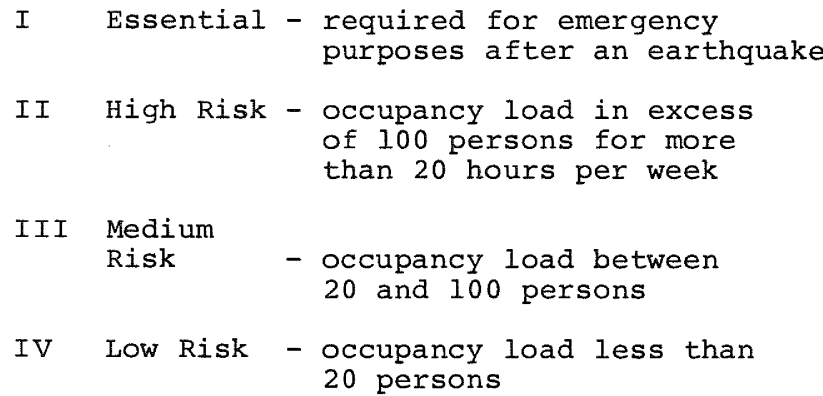

Los Angeles is included in the most seismically active region of the United States, namely seismic zone 4 of the Uniform Building Code.

The horizontal force factors based on the rating classification are:

$\begin{array}{ll}\text { Classification I } & 0.186 \mathrm{~g} \\ \text { Classification II } & 0.133 \mathrm{~g} \\ \text { Classification III \& IV } & 0.100 \mathrm{~g}\end{array}$

Detailed provisions are included for parts and portions of structures.

A simple external visual survey was made of every building in the City allowing four inspectors over a two year period to identify 8,000 buildings, the majority being industrial and commercial which will probably require upgrading. The computerised information resulting from the survey indicates that $84,000,000$ sq.ft. $(7,800,000 \mathrm{sq.m.})$ of area is involved, with upgrading estimated to cost between $\$ \frac{1}{2}-1$ billion at today's costs and affect between 200,000 and 400,000 people depending on the time of day.

A very detailed laboratory and onsite testing programme has been carried out and suggested testing procedures are set down later in this paper.

Typical allowable stresses for existing materials under seismic shear

Table No. 68-D:

Unreinforced Masonry Walls:

Classification Max. Ratio Unsupported Seismic Height or Length to in-plane Thickness Shear Stress based on Gross Area
I

Not applicable

II

9

III

IV

* may be increased by testing.

Horizontal Diaphragms:

(a) Roofs with straight sheathing and roofing applied directly to sheathing

(b) Roofs with diagonal sheathing and roofing applied directly to sheathing

(c) Floors with straight tongue and groove sheathing

$1501 \mathrm{~b}$ per ft. (2190 N per $\mathrm{m}$ ) Not applicable 3p.s.i.* $(21 \mathrm{kPa})$

3p.s.i.*

$(21 \mathrm{kPa})$

3p.s.i.*

$(21 \mathrm{kPa})$ (d) Floors with straight sheathing $3001 \mathrm{~b}$ per ft. and finished wood flooring
$4001 \mathrm{~b}$ per $\mathrm{ft}$. $(5,840 \mathrm{~N}$ per $\mathrm{m})$

$1501 \mathrm{~b}$ per ft. $(2,190 \mathrm{~N}$ per $\mathrm{m})$

$(4,380 \mathrm{~N}$ per $\mathrm{m})$ 
(e) Floors with diagonal sheathing and finished wood flooring

(f) Floors or roofs with straight sheathing and plaster applied to the joist or rafters

Shear Walls:

(a) Wood stud walls with wood lath and plaster

(b) Wood stud walls with plaster lath other than wood lath

$4001 \mathrm{~b}$ per ft. $(5,840 \mathrm{~N}$ per m)

Add $501 \mathrm{~b}$ per ft. $(730$ $\mathrm{N}$ per $\mathrm{m}$ ) to (a) and (c)

$50 \mathrm{lb}$ per $\mathrm{ft}$. (730 N per m) each side

$1001 b$ per ft. $(1,460 \mathrm{~N}$ per m)

It should be noted that Los Angeles completed some years ago, a programme of parapet and associated roof diaphragm upgrading.

\subsection{San Francisco -}

The City has a massive problem in that preliminary surveys indicate that some 11,000 unreinforced masonry buildings could require upgrading. No programme has been formalised for upgrading old buildings, although some emphasis is being placed on reconstituting the Seismic Safety and Hazard Survey Advisory Committee with the initial task of making recommendations for the correction of unreinforced masonry buildings.

The City is actively pursuing a policy of parapet and associated roof diaphragm upgrading.

\section{MASONRY TESTING:}

The following information is taken directly from the City of Los Angeles draft ordinance, Division 68 - Earthquake Hazard Reduction in Existing Buildings ${ }^{8}$.

SECTION 91.6807

\section{(e) MINIMUM ACCEPTABLE QUALITY OF EXISTING UNREINFORCED MASONRY WALLS}

\section{General Provisions -}

All unreinforced masonry walls utilized to carry vertical loads and seismic forces parallel and perpendicular to the wall planes shall be tested as specified in this section. All masonry quality shall equal or exceed the minimum standards established herein or shall be removed and replaced by new materials. Alternate methods of testing may be approved by the Department. Nothing shall prevent pointing with cement mortar of all the masonry wall joints before the tests are first made. If the exterior joints are pointed then the inside face must also be pointed. Prior to any pointing, the wall surface must be sand or water blasted to remove loose and deteriorated mortar. All preparation and cement mortar pointing shall be done under the continuous inspection of a registered deputy inspector with a subsequent written report to the Department. All testing shall be performed by an approved testing agency in accordance with the requirements specified in this

\section{Sub-section.}

\section{EXCEPTION :}

Unreinforced masonry walls which carry no design loads other than their own weight may be considered as veneer if they are adequately anchored to new supporting elements.

\section{Number And Location of Tests -}

The quality of mortar in all masonry walls shall be determined by performing in place shear tests or by testing eight inch diameter cores. The minimum number of tests shall be two per wall or line of wall elements resisting a common force, or 1 per 1500 square foot of wall surface, with a minimum of eight tests in any case. The exact test or core location shall be determined at the building site by the licensed engineer or architect responsible for the seismic analysis of the subject building. The results of all tests or coring shall be recorded and reported.

\section{In-Place Shear Tests -}

The bed joints of the outer wythe of the masonry shall be tested in shear by laterally displacing a single brick relative to the adjacent bricks in that wythe. The opposite head joint of the brick to be tested shall be removed and cleaned prior to testing. The minimum quality mortar in 80 per cent of the shear tests shall not be less than the total of 30 p.s.i. plus the axial stress in the wall at the point of the test. The shear stress shall be based on the gross area of both bed joints and shall be that at which movement of the brick is first observed. (See Figure 2).

\section{Core Tests -}

A minimum number of mortar test specimens equal to the number of required cores shall be prepared from the cores and tested as specified herein. The mortar joint of the outer wythe of the masonry core shall be tested in shear by placing the circular core section in a compression testing machine with the mortar bed joint rotated 15 degrees from the axis of the applied load. The mortar joint tested in shear shali have an average ultimate stress based on the gross area of 20 p.s.i. The average shall be made from the total number of cores made. If test specimens cannot be made from cores taken the shear value shall be reported as zero. The results of all coring and shear testing shall be reported. (See Figure 3).

\section{(f) TESTING OF SHEAR BOLTS}

One-fourth of all new shear bolts and dowels embedded in unreinforced masonry walls shall be tested by a registered deputy inspector using a torque calibrated wrench to the following minimum torques :

$1 / 2$ " diameter bolts or dowels $=40$ foot-1bs $5 / 8$ " diameter bolts or dowels $=50$ foot-lbs $3 / 4$ " diameter bolts or dowels $=60$ foot-lbs 


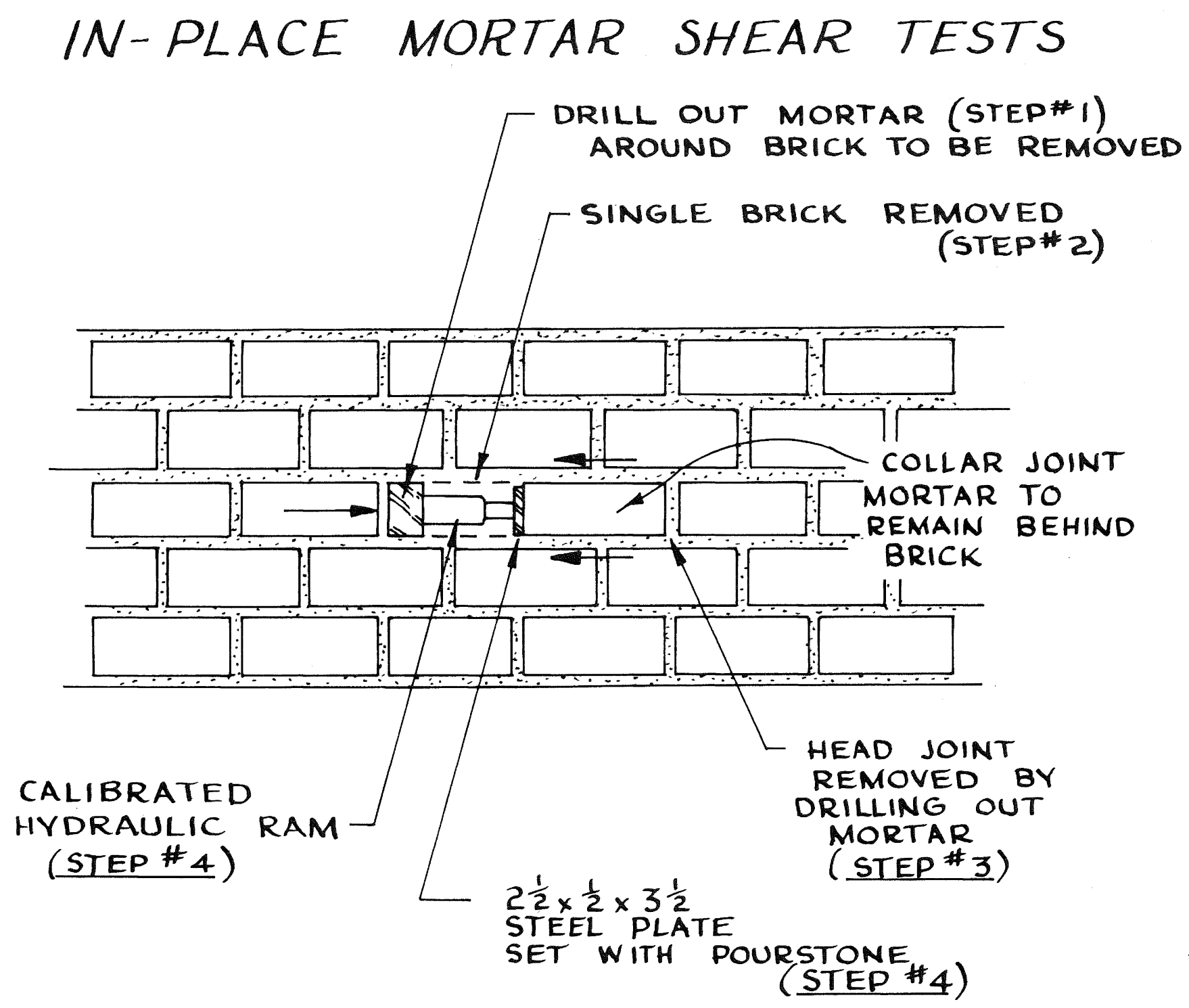

PROCEDURE:

Step 1. Existing mortar drilled out with 5/16" diameter masonry drill x 4" long.

Step 2. Remove brick.

Step 3. Drill out head joint mortar $\times 4$ " deep.

Step 4. Install jack and test.

Step 5. "v" lime mortar $=\frac{P(\text { load in lbs) }}{\text { (Ibs/sq. in) }}$
$2 \times$ Flat area of brick (sq. ins)

(Typically 3-7/8" $\times$ 8")

Source - Reference 10.

FIGURE 2. 
No bolts exceeding $3 / 4 "$ shall be used. All nuts shall be installed over malleable iron or plate washers when bearing on wood and heavy cut washers when bearing on steel.

\section{(g) DETERMINATION OF ALLOWABLE STRESSES FOR DESIGN METHODS BASED ON TEST} RESULTS

\section{Design Shear Values -}

Design seismic in-plane shear stresses greater than permitted in Table No. 68-D shall be substantiated by tests performed as specified in Section 91.6807 (e) 3. and 4 .

Design stresses shall be related to test results obtained as noted in Table No. 68-G. Intermediate values between 3 and 5 p.s.i. may be interpolated.

TABLE NO. 68-G

ALLOWABLE SHEAR STRESS FOR TESTED UNREINFORCED MASONRY WALLS

Eighty percent of test results in Average test results of cores in psi

Seismic inplane shear based on gross area

30 plus axial stress

3 p.s.i. (1)

40 plus axial stress

4.p.s.i. (1)

50 plus axial stress or more

5 p.s.i. (1)

or more. (a) Shotcreting or guniting of existing walls is one of the more expensive upgrading procedures, but this application of a reinforced concrete skin tied into the existing masonry walls ensures full integrity of the structure and its component parts under lateral force loading.

Perhaps the most impressive example of this method is the $\$ 60 \mathrm{~m}$ upgrading of the California state Capitol building constructed originally in 1874 of brick masonry with cast iron columns and cast iron window frames and decorative features that look like carved stone. The old building is considered an irreplaceable landmark of great historic significance and lateral force criteria were developed out of special studies of site seismicity and soil-structure interaction.

To reduce deadweight, two wythes of brickwork were removed from the inside face of critical walls and after the placing of reinforcement and dowels to anchor the new concrete into the existing brickwork, a shorcrete layer varying from $9 "$ to 12 " (225 to $300 \mathrm{~mm}$ ) in thickness was placed. Dowels consisted of $1 "$ diameter $(25 \mathrm{~mm})$ deformed reinforcing bars

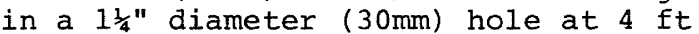
(1.3m) centres both ways. An epoxy resin anchored the dowel into the brickwork and test results for tension pullout indicated an ultimate load of 1 Kip per inch ( 1.75 $\mathrm{kN}$ per $\mathrm{cm}$ ) of bolt.

New foundations and floor slabs were required with heavy reinforcement transferring shear forces into the foundations.

The remaining methods emphasize the need for frame or shear wall integrity, rather than element integrity and accept that considerable damage to the building may result from seismic forces.

(b) Perhaps the most obvious and in many cases, adequate, method of upgrading an old building is to improve the connection from wall to floor and roof diaphragms and in some cases improve the diaphragm action by steel bracing or timber overlays. The details given earlier in relation to the City of seattle are typical.

(c) The addition of vertical wall bracing, often in the ' $K$ ' or ' $A$ ' shape for maximum visibility, ease of construction and fabrication, is particularly effective in stabilising many buildings in the shorter transverse direction, but may also be necessary in the longer longitudinal direction. To minimise overturning problems the designer should endeavour to mobilise the greatest possible length of wall. The immediate objection to this method of upgrading is the apparent incompatibility of stiffness between the existing masonry and the additional steelwork. The use of ' $K$ ' and ' $A$ ' frame bracing, sensibly sized and tied into the masonry can, however, ensure floor stability. A rule of thumb quoted by one 
San Francisco designer was to limit interstorey deflection of the steelwork to a maximum of 1 inch ( $25 \mathrm{~mm})$.

(d) The storey height associated with many older buildings is incompatible with acceptable slenderness ratios under combined vertical and lateral loads, and also under lateral face loading. Strapping, with timber or steel can easily reduce vertical and horizontal spans to acceptable levels.

(e) Blockwork and reinforced concrete shear walls and frames can be added, but the designer must be aware of the additional weight added to the structure. Depending on building height, lath and plaster can accommodate lateral forces on upper floors with ply, adequately fixed being used at lower levels. The uplift forces and connections must be checked.

All upgrading methods require a clear appreciation of the structural system that will transfer vertical and lateral forces from throughout the building to the foundations. The designer must ensure that members and connections along this load path are adequate and give careful attention to the need to positively interconnect all elements and parts of the structure.

\section{CONSTRUCTION:}

It should be evident that lump sum tendering is not appropriate for construction work associated with the structural upgrading of old buildings. It is desirable to use a contractor experienced in this specialised field, in the handling of older materials and who has competent site staff able to adapt the design philosophy, in conjunction with the designer, as the building is opened up.

A common contractural relationship is a fixed lump sum to cover the builder's estimated overheads with a percentage margin added to all nett costs.

\section{6. $\cos T S$ :}

Wide variation is evident. In Los Angeles structural upgrading was within the range of $\$ 6-12$ per sq.ft. $(\$ 65-130$ per sq.m.). In San Francisco, the range was quoted as $\$ 8-18$ per sq.ft. ( $\$ 86-194$ per sq.m.) with total refurbishing costs ranging from $\$ 35-45$ per sq.ft. (\$377-484 per sq.m.). New construction was in the range $\$ 70-80$ per sq.ft. (\$754-861 per sq.m.).

It should also be remembered that refurbishing is often completed within a lesser period than new construction and that it can have significant planning advantages.

It may be of interest to compare the above figures with recent examples in Auckland City of structural upgrading costs:

(a) Two storey building upgraded with plywood overlay to floor, improved connection between two brickwork skins - completed in 1977.

$\$ 2.36$ per sq.ft. $(\$ 25.40$ per sq.m.)

(b) Two and three storey masonry building of historic significance, upgraded with plywood overlay to floors, improved diaphragm connections and concrete floor at ground level to tie foundations together. costs)

$\$ 7.35$ per sq.ft. $(\$ 79.00$ per sq.m. $)$.

(c) Two storey masonry building of historic significance. Upgraded with improved diaphragm connections, concrete floor at ground level to tie foundations together and additional parapet and ornamentation supports. Estimated 1980 costs.

$\$ 3.40$ per sq.ft. $(\$ 36.60$ per sq.m. $)$.

7. FINANCIAL INCENTIVES:

A number of financial incentives are available to encourage rehabilitation.

In the Pioneer Square Historic District of Seattle, typical incentives include :

\section{(a) Five Year Amortization}

Owners of commercial or income producing property are allowed to amortize, using a straight line method, the cost of certified rehabilitation of a structure over a five year period.

\section{(b) Accelerated Depreciation}

Accelerated depreciation provisions apply to the total value of the property and improve the early cash flow of a project.

\section{(c) Ten Per Cent Investment Tax Credit}

This provision allows the owner of a building qualified for rehabilitation to deduct directly from taxes owed, an amount equal to ten per cent of the rehabilitation cost. The first year provides a dollar for dollar credit against taxes owed up to $\$ 25,000$. Taxes owed beyond this amount may be reduced on a percentage basis:

60 per cent in excess of $\$ 25,000$ the first year, 70 per cent the second,

80 per cent the third and 90 percent the fourth year and any year beyond.

(d) HUD Section 312 Loans

The Department of Housing and Urban Development provides three per cent interest loans for the rehabilitation of residential, commercial or mixed use properties.

(e) Historic Preservation Grant-in Aid Programme

Historic Preservation Grants are fifty 
per cent matching grants to private organisations, individuals and Government agencies for the survey, planning, acquisition and development of historic structures.

(f) National Preservation Revolving Fund

The programme provides low interest loans to non-profit or public agencies for improving historically or architecturally significant properties. These loans range from $\$ 25,000$ to $\$ 75,000$ and are generally for a three to five year period.

\section{NEW ZEALAND PRACTICE:}

\subsection{General -}

New Zealand has for many years acknowledged the possibility of earthquakes and included in design codes, provision for lateral seismic forces. Many buildings constructed prior to the introduction of these design provisions, are not able to resist seismic forces and in the event of an earthquake, are hazardous to those in and around the building. Should an earthquake occur, the cost to the community in terms of life, injury and damage will depend on the intensity of the earthquake, the adequacy of the buildings and the number of people at risk.

\subsection{Legislation -}

In 1968 legislation was introduced that allowed local authorities who so wished and had made the necessary application, to require the upgrading or removal of specific types of buildings that would not withstand moderate earthquakes.

A moderate earthquake is defined as one that imposes seismic forces onehalf those specified in N.Z.S. 1900, Chapter 8:1965, for the zone in which the building is situated. Where the building has its ultimate load capacity exceeded in such a moderate earthquake, then the local authority may either require the building to be secured to its satisfaction or demolished.

The legislation has a number of unusual features, not the least of which is the lack of understanding and acceptance after some twelve years on the statute book.

(a) Its adoption by a local authority is not mandatory.

(b) It applies only to certain types of buildings.

(c) It uses a seismic level of one half the appropriate zone coefficient. In terms of N.Z.S. 4203:1976, and using the criteria associated with small buildings of limited ductility, the statutory level is around one twentieth of current design standards. Does the present statute provide insufficient protection or does the new code overstate likely lateral force levels? It is worth nothing that the most recent Uniform Building code, which sets design standards in seismically more active areas than New Zealand does not penalise nonductile structures to the same degree as the most recent local code.

(d) The Act refers to ultimate capacity.

No national standard for the ultimate design of masonry structures exists and hence it is necessary to factor down the applied seismic force if working stress parameters are to be used.

(e) The Act requires, as one alternative, the "securing of the building to the satisfaction of the Council". In other words, the standard to which the building should be upgraded is determined by the controlling local authority. A recent survey of major local authorities showed a wide variation in upgrading standards ranging from partial compliance with N.Z.S. 1900: Chapter 8, 1965, to full compliance with N.Z.S. 4203:1976. Without clearer national guidelines, frustration, wasted time and money and an inadequate end result is likely with present procedures.

It is my personal view that the Act, operative in 1968, refers to the operative code of that time viz. N.Z.S. $1900:$ Chapter 8, 1965.

Buildings constructed for many years prior to this date were constructed to a base seismic force of around 1965 code levels, and it is neither unrealistic or impractical to require upgrading to that standard. The end result is buildings commensurate in strength to those of the 1940-1970 era. If the limited ductility provisions of N.Z.S. 4203:1976, are to be applied, they impose upgrading standards which are both incompatible with the great majority of buildings constructed prior to the introduction of the recent code and impose practical and monetary penalties which may well preclude the conservation of many older structures.

\subsection{Timing and Priorities -}

A building could be upgraded at the time a building permit application is made, the requirement being related to the extent of work contained in the permit application.

Present indications are that this would result in extremely slow progress in removing seismically hazardous buildings and have no direct relationship with desirable priorities.

Alternatively, buildings could be upgraded to a reasoned programme in accordance with desirable priorities. 
In 1973 the New Zealand National Society for Earthquake Engineering introduced "Recommendations for the Classification of High Earthquake Risk Buildings"12. A useful document, but one which I believe is in urgent need of review.

If it is accepted that upgrading is required to save life and prevent injury, then occupancy loading in and around the building should be the base criteria for ordering priorities, subject to the overiding need to upgrade structures containing essential services.

The upgrading periods depend on a multiplication factor $k$, where $k$ "is a factor, selected by the individual Council to suit local conditions". The suggested periods, resulting from building surveys and the use of the classification system, range from $0-36$ years. I suspect that these periods have no relation to upgrading costs, and economic and practical resources but have been considered a reasonable time span. I would question whether any attempt has been made to quantify expenditure against time over the 36 year period. Local surveys indicate that a much reduced time span, generally in the range 10-20 years is obtained through the use of this means of classification.

I consider that the present situation is unsatisfactory and if the Profession is to retain credibility in this increasingly important area of building conservation, then urgent action must be taken to set clear objectives and the means by which such objectives are to be achieved.

\subsection{Action Areas -}

1. A national code is required to clarify the intent of the legislation and to produce guidelines on upgrading standards and priorities. Such a code requires considerable input on economic, practical and social factors and committee membership should reflect these vital areas of interest. Considerable background material is available and should be used.

2. If, as is probable, upgrading can only be completed over a long time period, guidelines for the removal of "particular hazards" e.g. parapets, gables, chimneys, ornamentation and an appropriate reduced time scale should be prepared.

Past experience has shown that a major life safety hazard, particularly during moderate earthquakes, is due to falling objects from parapets, balconies, chimneys, ornamentation and roof mounted equipment. Many older buildings provide visual and practical evidence of decay by reason of the minor collapse of building elements on to footpaths and carriageways over recent years.

Initial study suggests that a programme of remedial/removal works to eliminate these particular hazards, with emphasis on central business districts and other major occupancy areas, could be carried out within a relatively short period of time and at reasonable cost.

3. Financial incentives should be sought from Government to assist with the cost of upgrading to meet higher safety standards.

4. There is an urgent need for local studies to proceed in the following areas, to provide information on critical elements associated with older buildings.

(a) Effectiveness of timber diaphragms and diaphragm connections.

(b) Construction methods, standards and material strengths, with particular reference to old masonry structures.

(c) Practical testing procedures.

(d) Diaphragm effectiveness of ceilings and roofs and their interrelationship with timber diaphragms.

(e) Effectiveness of non masonry walls and internal partitions.

\subsection{Conclusion -}

Greatly increased emphasis is now being placed on building conservation. National guidelines for the reduction of hazards associated with high earthquate risk buildings must be urgently clarified having regard to practical, economic, social and technical requirements and resources.

NOTE :

The opinions expressed in this paper are those of the Author, and should not be construed as Auckland City Council policy or practice.

\section{REFERENCES :}

1. Uniform Building Code, 1979 Edition - International Conference of Building Officials.

2. Seattle Building Code Supplement Ordinance 108508 - City of Seattle, Department of Buildings.

3. Information Bulletin No. 02 City of Seattle, Department of Buildings.

4. State Historical Building Code State of California.

5. City of Santa Rosa - Ordinance 2052 .

6. City of Long Beach - Ordinance No. C. 5276, Long Beach Municipal Code.

7. City of Long Beach - Specifications for Assessing the Capacity of Unreinforced Masonry Buildings, Long Beach Department of Planning and Building. 
8. City of Los Angeles - Preliminary

Draft, Division 68 - Earthquake

Hazard Reduction in Existing Buildings.

9. Pioneer Square Profile - An Update

on Redevelopment. City of Seattle,

Department of Community Development.

10. Tentative Los Angeles Ordinance

and Testing Pregramme for Unreinforced

Masonry Buildings, - B. Schmid,

J. Kariotis, E. Schwartz.

11. Local Government Amendment Act,

1979 (previously Municipal

Corporations Act, 1954).

12. Recommendations for the Classification

of High Earthquake Risk Buildings -

New Zealand National Society for

Earthquake Engineering.

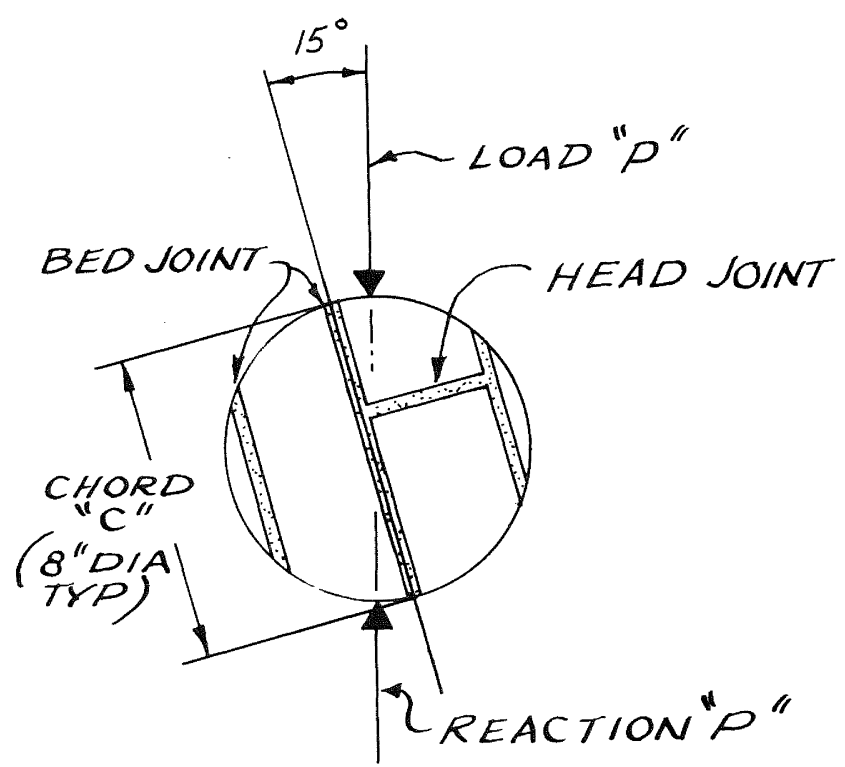

FRONT VIEW

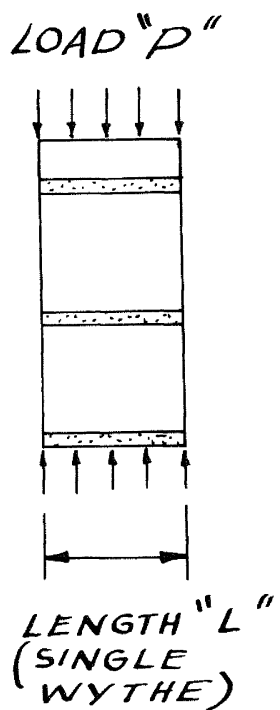

SIDE VIEW

Source - Reference 10.

FIGURE 3. 